\title{
Årsberetninger 2020
}

ÅRSBERETNING

\author{
De nordiske kriminalistforeninger
}

\section{Kriminalistforeningen i Danmark}

Foreningens formand var i 2020 ledende overlæge Dorte Sestoft. Bestyrelsen bestod endvidere af kontorchef Anne-Julie Boesen Pedersen (kasserer og næstformand), rigsadvokat Jan Reckendorff, departementschef Barbara Bertelsen, professor Thomas Elholm, direktør for Kriminalforsorgen Thorkild Fogde, politidirektør Arne Vedsted Gram, regionsdirektør Anne Marie Heckscher, højesteretsdommer Poul Dahl Jensen, landsdommer og formand for dommerforeningen Mikael Sjöberg, forsvarsadvokat Sysette Vinding Kruse samt professor i kriminologi ved Århus universitet Anette Storgaard.

I det forløbne år har der været afholdt to bestyrelsesmøder.

Centerchef Ole Hansen og forsvarsadvokat Sysette Vinding Kruse fungerede som foreningens interne revisor.

Efter generalforsamlingen i København den 5. februar var der møde med titlen: Udvisning af Psykisk Afvigende Kriminelle Udlændinge med oplæg fra Anklager Nana Kryger la Cour samt Peter Vedel Kessing, cand.jur., ph.d., LLM fra Institut for Menneskerettigheder.

Lokalafdelingen på Fyn har afholdt et møde den 16. januar: Et viktimologisk blik på voldtægtssagen i retssystemet med oplæg fra Tine Søberg, specialkonsulent ved Nationalt Forebyggelsescenter Rigspolitiet, Michael Lind, efterforsker ved Sydøstjyllands Politi og Gyrithe Trautner Ulrich vicestatsadvokat ved Statsadvokaten i København.

Den 16. september afholdtes mødet: Kan kriminalitet forebygges/forudsiges? - Screeningsværktøjer til brug for ungdomskriminalitetsnævnet med oplæg fra professor Anette Storgaard, Lektor em. Morten Ejrnæs samt chefkonsulent Maria Bislev.

Grundet Covid-19 måtte foreningen aflyse de øvrige planlagte gå-hjemmøder.

Ved årets udgang havde Dansk Kriminalistforening et æresmedlem og 219 betalende medlemmer, hvoraf de 5 var kollektive medlemskaber for mindre arbejdspladser (op til 20 medarbejdere) og 8 kollektive medlemskaber for 
større arbejdspladser. På trods af at foreningen fik 17 nye medlemmer, er det en nedgang på 34 medlemmer siden 2019.

Se mere på www.kriminalistforeningen.dk eller på www.facebook.com/ kriminalistforeningen/

Sekretær Laura Arendt, e-mail: sekretariat@kriminalistforeningen.dk

Dorte Sestoft

Formand

\section{Suomen Kriminalistiyhdistys - Kriminalistföreningen i Finland}

Föreningens styrelse har under redogörelseåret haft följande sammansättning: planerare Petri Danielsson, ordförande; universitetslektor Dan Helenius, viceordförande; advokat Mervi Salo, sekreterare; och doktorand Karoliina Suonpää, kassör. Styrelsens övriga medlemmar bestod av följande personer: specialsakkunnig Anni Karnaranta, rättspsykiater Mika Rautanen och häradsåklagare Yrjö Reenilä. Styrelsens suppleanter bestod av följande personer: doktorand Kristiina Koivukari och överinspektör Leena Mäkipää.

På grund av de omständigheter som orsakades av coronaviruset flyttades föreningens årsmöte och det diskussionstillfälle som skulle hållas i samband med det. Årsmötet anordnades 18.8.2020 på distans i Vetenskapernas hus. I samband med årsmötet ordnades inget annat program.

Vid årets slut hade föreningen 108 medlemmar.

\section{Kriminalistforeningen i Island - Sakfræðifélag Íslands}

Foreningens formand er professor Ragnheiður Bragadóttir.

I 2020 var der intet møde i foreningen.

\section{Årsberetning 2020 for Den Norske Kriminalistforening}

Grunnet koronapandemien, og lockdown som ble innført i Norge fra 12. mars 2020, har Kriminalistforeningen dessverre ikke fått avholdt noen arrangementer i år. 
Det var planlagt et debattmøte med teamet «Kriminalpolitikkens ideologiske blindsone - Hvor er strafferetten på vei?», den 19. november 2020. Debatten skulle ta for seg den dreiningen man har sett de senere år - fra tiltaltes rettigheter til fornærmedes rettigheter. I forlengelse av dette, stilte vi spørsmålet: Hvor blir det av den politiske debatten om kriminalspørsmål i dag? Er det i det hele tatt noen uenighet blant partiene? Hvor er strafferetten på vei, og er vi fornøyde med utviklingen?

Panelet skulle bestå av Anders Løvlie (Førsteamanuensis ved juridisk fakultet, Universitetet i Oslo), Sverre Flaatten (Førsteamanuensis, Politihøgskolen), Nora Hallén (Advokat og partner i AdvokatfirmaetElden), Michael Tetzschner (Stortingsrepresentant for Høyre) og Petter Eide (Stortingsrepresentant for SV). Omtrent en uke før arrangementet skulle avholdes, ble det innført nye koronarestriksjoner i Oslo som ledet til at alle innendørs arrangementer måtte avlyses. Vi planlegger å gjennomføre debatten igjen når samfunnet åpner mer opp igjen.

Foreningens styre bestod av følgende medlemmer:

- førstestatsadvokat Runar Torgersen, Riksadvokatembetet (leder);

- Bendik Falch-Koslung, Advokatfirmaet Larsen \& Co (nestleder);

- Lucy Furuholmen, advokat ved Regjeringsadvokatembetet;

- Kjersti Lohne, postdoktor, Institutt for kriminologi og rettssosiologi, Universitetet i Oslo

- Heidi Mork Lomell, professor, Institutt for kriminologi og rettssosiologi, Universitetet i Oslo

- seniorkonsulent Per Jørgen Ystehede, Institutt for kriminologi og rettssosiologi, Universitetet i Oslo (varamedlem).

- Nils Gunnar Skretting, stipendiat, institutt for kriminologi og rettssosiologi, (varamedlem)

Foreningens revisor var advokat Nora Hallén. Foreningens sekretær var advokatfullmektig Hedda Larsen Borgan, Advokatfirmaet Sulland.

Foreningen hadde ca. 150 medlemmer.

\section{Svenska Kriminalistföreningens årsberättelse 2020}

Vid Svenska Kriminalistföreningens årsmöte, som på grund av coronapandemin ägde rum digitalt genom utskick till medlemmarna den 26 oktober 2020, valdes justitierådet Agneta Bäcklund till ordförande i föreningen. Till styrelseledamöter omvaldes advokaten Johan Eriksson, biträdande säkerhetspolischefen Charlotte von Essen, forsknings- och utredningsrådet Erik Grevholm, 
utvecklingschefen Anders Hall, kriminalvårdsdirektören Hanna Jarl, professorn

ÅRSBERETNING

Jerzy Sarnecki och universitetslektorn Erik Svensson. Till nya styrelseledamöter valdes vice riksåklagaren Katarina Johansson Welin, expeditionschefen Jenny Kvarnholt, hovrättspresidenten Anders Perklev och rättssakkunniga Eva-Lena Wahlin.

Till revisor omvaldes departementsrådet Mattias Larsson och hovrättsrådet Christer Lundh. Till revisorssuppleant omvaldes förbundsjuristen Anna Kers.

Styrelsen har under året haft tre protokollförda sammanträden.

Under året har föreningen arrangerat en pubkväll som ägnades åt den breddade hotbilden mot Sverige. Vid mötet beskrev säkerhetspolischefen Klas Friberg hur hoten mot och inom Sverige ser ut och har förändrats under de senaste åren, och vad som behövs för att stärka säkerhetsskyddet.

Vid årets utgång hade föreningen cirka 270 medlemmar. 